\title{
Demonstration of a cytotoxin from Campylobacter
} jejuni

\author{
WONG PHOOI YEEN, SAVITHRI D PUTHUCHEARY, TIKKI PANG
}

From the Department of Medical Microbiology, Faculty of Medicine, University of Malaya, Kuala Lumpur, Malaysia

SUMMARY A 48-hour culture filtrate of Campylobacter jejuni was found to produce cytopathic effects on three human cell lines-that is, HeLa, MRC-5 and Hep-2. The cytopathic effects observed include cell rounding, loss of adherence and cell death after 24-48 h of incubation. Such morphological changes were observed with eight of the eleven strains of Campylobacter jejuni isolated from the blood/stools of patients who suffered from either acute gastroenteritis or septicaemia. The toxic factor did not retain its activity after treatment at $100^{\circ} \mathrm{C}$ for $30 \mathrm{~min}$. Trypsinisation of the filtrate totally abolished its toxic activity thus indicating that it was probably protein in nature. It is most probably an extracellular toxin as bacterial sonicates did not produce any toxic effect. This study reports the finding of toxic factor(s) in the culture filtrate of Campylobacter jejuni which is cytotoxic to human tissue culture cells.

Campylobacter jejuni is a recently recognised cause of human acute/subacute diarrhoeal disease. ${ }^{1-3}$ The organism is responsible for $3-11 \%$ of cases of infective diarrhoea reported in Europe, Africa, Australia and North America. ${ }^{1345}$ In Sweden, Campylobacter alone accounted for approximately $11 \%$ of diarrhoeal cases and was even more common than Salmonella. ${ }^{6}$ Despite considerable documentation of human infections with this organism, the exact mechanism(s) involved in disease production is not known. The presence of bacteraemia in some patients and the frequent finding of dysenteric stools similar to that seen in shigellosis suggest that Campylobacter jejuni may be an invasive organism. The possibility of direct tissue invasion is further supported by the demonstration, by electron microscopy, of the presence of vibrio-like organisms in chicken embryo cells as well as in the caecal wall of neonatal chickens following intragastric inoculation. ${ }^{78}$

However, the significance of these findings has yet to be established, particularly in view of the failure of many investigators to demonstrate invasiveness by the classical Sereny test. ${ }^{910}$ The various clinical features of patients with Campylobacter enteritis raise the possibility of toxin-mediated effects ${ }^{11}$-for example, tissue damage of the jejunum and colon

Accepted for publication 21 June 1983 may be caused by a cytolytic exotoxin like that produced by Clostridium difficile, and the frequent occurrence of profuse watery stools in some diarrhoeal patients may probably be due to the presence of an enterotoxin.

It was thus the aim of this study to investigate the probable production of toxin by Campylobacter jejuni isolated from human cases. Various tissue culture cell lines have been employed to detect the presence of toxic factor(s) found in the culture filtrate of the organism.

\section{ISOLATES OF CAMPYLOBACTER JEJUNI}

Eleven isolates of Campylobacter jejuni were studied. All these isolates were obtained from the blood or stool cultures of infants and adults admitted to the University Hospital, Kuala Lumpur with acute gastroenteritis or septicaemia. Three strains (CJ01, CJ02, CJ03) were confirmed to be Campylobacter jejuni biotype 1 by Dr MB Skirrow (Public Health Laboratory, Worcester, United Kingdom). All other strains were confirmed as Campylobacter jejuni by standard biochemical tests but have not been biotyped. Isolates were stored in freeze-dried powder form, and none was passaged more than four times after isolation and before use in any of the tests described below.

PREPARATION OF CELL-FREE FILTRATE

Ten colonies of Campylobacter jejuni were grown in 
$10 \mathrm{ml}$ of nutrient broth (Difco) at $42^{\circ} \mathrm{C}$. After $48 \mathrm{~h}$, cultures were centrifuged at $5000 \mathrm{~g}$ for $15 \mathrm{~min}$ and the supernatant were filtered (pore-size, $0.22 \mu \mathrm{m}$; Millipore Corp, USA). The resulting supernatant represented the cell-free filtrate which was then tested for sterility by streaking on Campylobacter selective medium or Skirrow's medium ( $5 \%$ lysed ox blood agar supplemented with vancomycin $10 \mu \mathrm{g} /$ $\mathrm{ml}$, polymyxin B $2.5 \mathrm{IU} / \mathrm{ml}$, trimethoprim lactate $5 \mu \mathrm{g} / \mathrm{ml}$, Oxoid, England) and incubated at $42^{\circ} \mathrm{C}$ in $10 \% \mathrm{CO}_{2}$.

For the heat stability test, the filtrate was heated at $56^{\circ} \mathrm{C}$ for $30 \mathrm{~min}$ or at $100^{\circ} \mathrm{C}$ for $30 \mathrm{~min}$.

\section{MAINTENANCE OF CELL LINES}

MRC-5 (human embryonic fibroblasts), Hep-2 (human tumour epithelial cells), L929 (mouse fibroblasts) and Vero (African Green monkey kidney) cells were grown in Dulbecco's modification of Eagle's Medium (Flow Lab, USA) supplemented with $10 \%$ fetal bovine serum, $100 \mathrm{IU} / \mathrm{ml}$ of penicillin and $100 \mu \mathrm{g} / \mathrm{ml}$ of streptomycin (Gibco Lab, USA). The cells were seeded in tissue culture flasks (50 ml, Costar, USA) and incubated at $37^{\circ} \mathrm{C}$ under normal atmospheric conditions, except L929, which required $10 \% \mathrm{CO}_{2}$.

HeLa cells (human tumour epithelial cells) were grown in Eagle's Minimal Essential Medium (Flow Lab, USA) supplemented with $10 \%$ fetal bovine serum, $100 \mathrm{IU} / \mathrm{ml}$ of penicillin and $100 \mu \mathrm{g} / \mathrm{ml}$ of streptomycin. Both PMK (primary monkey kidney) and MK-2 (Rhesus monkey kidney) cells required medium 199, 5\% glutamine and in the case of PMK, Hepes buffer was added. These three cell lines were grown in sterile screw capped glass tubes at $37^{\circ} \mathrm{C}$.

When the cells become confluent, the growth medium was removed and replaced with minimal medium containing only $2 \%$ serum.

\section{TESTING OF CYTOTOXIC ACTIVITY}

The seven cell lines were used for the detection of cytotoxicity. Confluent monolayers of these cell lines were incubated with the cell-free filtrate at various dilutions at $37^{\circ} \mathrm{C}$. Twofold dilutions of the filtrate were tested $(1 / 2$ to $1 / 32)$. Control groups were included in which sterile nutrient broth incubated at $42^{\circ} \mathrm{C}$ for $48 \mathrm{~h}$ was inoculated onto the cell cultures. Cytotoxicity was assessed morphologically at six-hourly intervals by the presence of destructive changes and by the failure to exclude trypan blue.

\section{TR YPSINISATION OF CELL-FREE FILTRATE}

Protein content of the cell-free filtrate was determined by the Biuret method. $10 \mathrm{mg} / \mathrm{ml}$ of the filtrate was mixed with equal amount of trypsin (Sigma, USA) and incubated at $37^{\circ} \mathrm{C}$ for two hours
(pH 7.2). Soybean trypsin inhibitor (Sigma, USA) was added to the mixture before determination of $\underline{\partial}$ cytotoxicity.

SONICATED BACTERIAL CELL PREPARATION Ten colonies of each strain of Campylobacter jejuni picked from blood agar plates were suspended into $\frac{\overline{\bar{S}}}{\bar{D}}$ $1.0 \mathrm{ml}$ distilled water in a small glass tube. The bac- $\mathbb{\mathbb { Q }}$ terial suspension was then sonicated $(20 \mathrm{kc} / \mathrm{s}$, Branson cell disruptor, USA) for $15-20 \mathrm{~s}$ on ice. The suspension was then centrifuged at $4^{\circ} \mathrm{C}$ for $20 \mathrm{~min}$ at $\stackrel{\circ}{.}$ $5000 \mathrm{~g}$ and filtered. The filtrate was then tested for $\vec{\omega}$ cytotoxicity using HeLa and Hep-2 cell monolayers.

\section{Results}

On human cell lines (HeLa, MRC-5 and Hep-2), cell destruction occurred after incubation with $\vec{N}$ untreated filtrate of CJ01, CJ02 and CJ14 strains ${ }_{-j}^{\omega}$ for $24-48 \mathrm{~h}$, but not with the uninoculated control 윽 broth (Table 1). Cell rounding associated with nuclear pyknosis (Fig 1b) was a distinctive feature of $Z$ the cytopathic effects observed. There was loss of cell adherence of the monolayers and many of the $\frac{\Phi}{3}$ floating cells were found to be dead by trypan blue $\underset{\mathbb{Q}}{\mathcal{D}}$ exclusion. However, none of the animal cell lines was affected by these three culture filtrate $\mathscr{\odot}^{\circ}$ (Table 1). Culture filtrate of CJ03 strain showed no cytopathic effects on both the human as well as an mal cell lines. Seven other strains were tested onfy on HeLa and Hep-2 cells. Culture filtrates from five $\bar{\partial}$ out of these seven strains produced cytopathic effects identical to that already described. When $\stackrel{\square}{\perp}$ cell-free filtrates of CJ01, CJ02 and CJ14 strains $\underset{F}{\Rightarrow}$ were heated at $56^{\circ} \mathrm{C}$ for $30 \mathrm{~min}$, cytopathic effects $\frac{\mathrm{O}}{3}$ on HeLa and Hep-2 cells could still be observed (Table 2). However, treatment at $100^{\circ} \mathrm{C}$ for $30 \mathrm{~min}$, abolished the toxic activity (Table 2 ). This indicated that the toxic factor was a heat labile substance. In? addition, pretreatment of the filtrate with trypsin

Table 1 Result of a 1/8 dilution of cell-free filtrates of four $C$ jejuni on tissue culture cells

\begin{tabular}{llllll}
\hline Cell lines & Origin & \multicolumn{3}{l}{ Strain of C jejuni tested } \\
\cline { 3 - 6 } & & CJ01 & CJ02 & CJ03 & CJ14 \\
\hline HeLa & Man & + & + & - & + \\
Hep-2 & Man & + & + & - & + \\
MRC-5 & Man & + & + & - & + \\
Vero & Monkey & - & - & - & - \\
MK2 & Monkey & - & - & - & - \\
PMK & Monkey & - & - & - & - \\
L929 & Mouse & - & - & - & - \\
\hline
\end{tabular}

$+=$ presence of cytopathic effect.

- = absence of cytopathic effect.

Cytopathic effect was also detected at filtrate dilutions of $1 / 2$ and $1 / 4$ but not at $1 / 16$ or $1 / 32$. 

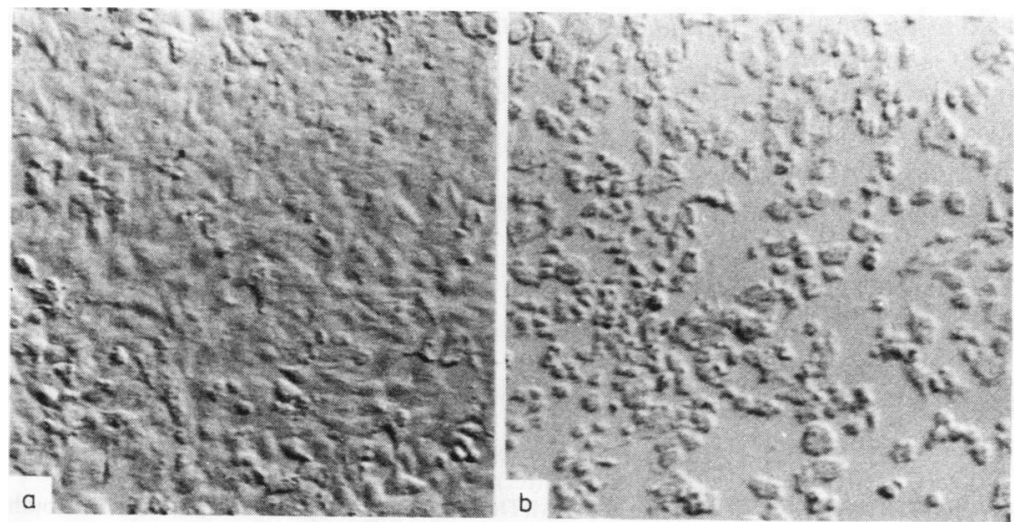

Fig. 1 (a) HeLa cell monolayer incubated with control (uninoculated) culture broth. (b) HeLa cell monolayer incubated with cell-free filtrate of CJ01 for $24-48 \mathrm{~h}$. Original magnification $\times 500$.

Table 2 Characterisation of the cell-free filtrate of three strains of $C$ jejuni showing toxic activity

\begin{tabular}{lll}
\hline $\begin{array}{l}\text { Treatment of } \\
\text { cell-free fitrate }\end{array}$ & \multicolumn{2}{l}{ Cytopathic effect observed } \\
\cline { 2 - 3 } & HeLa & Hep-2 \\
\hline $\begin{array}{l}\text { Untreated } \\
\text { Heated for } 30 \mathrm{~min} \text { at }\end{array}$ & + & + \\
$56^{\circ} \mathrm{C}$ & + & + \\
$100^{\circ} \mathrm{C}$ & - & - \\
Trypsinisation & - & - \\
Bacterial sonicates & - & - \\
\hline
\end{tabular}

totally prevented the cytopathic effects on HeLa and Hep- 2 cells, thus indicating that the toxic factor was probably protein in nature (Table 2 ). Finally, bacterial sonicates did not contain any toxic factor as shown by the absence of cytopathic effects on HeLa and Hep-2 cells thus suggesting that the toxic factor was most probably an extracellular product (exocytotoxin) rather than an endotoxin.

\section{Discussion}

The large global increase in the number of reports of enteric diseases caused by Campylobacter jejuni has stimulated many investigators to search for possible pathogenic mechanism(s) for this organism. Various studies suggest that the organism is enteropathogenic in man by means of its invasive properties. Evidence to support this proposal comes mainly from clinical studies such as the rapid rise of antibody titres post infection, ${ }^{12}$ the recovery of the organism from patients' blood in the acute phase of the disease ${ }^{1213}$ and the presence of intestinal congestion and haemorrhage at necropsy of a patient who died from Campylobacter infection. ${ }^{14}$ While the hypothesis of invasiveness is not firmly established, attempts to detect the production of a heat stable or heat labile enterotoxin analogous to those produced by Vibrio cholerae and certain strains of Escherichia coli have not been fully successful..$^{7} 10$

Skirrow has reported in his preliminary studies that 16 out of a 100 clinical Campylobacter isolates showed evidence of heat stable enterotoxin production by the suckling mouse assay. ${ }^{7}$ However, none of the culture filtrates of these isolates demonstrated enterotoxin activity on $Y_{1}$ adrenal cells indicating the absence of a thermolabile toxin. ${ }^{7}$ Manninen et $a l^{10}$ in their recent studies, were unable to demonstrate any enterotoxin activity from the culture filtrate of both human and animal Campylobacter species. However, it is hazardous to deduce that an enterotoxin is absent merely on the failure to demonstrate activity in an in vitro system. In some cases, as with Salmonella and Escherichia coli culture filtrates, partial purification is necessary or at least helpful in demonstrating an enterotoxin-like effect. ${ }^{15}$

Despite the failure in vitro to detect any classical enterotoxin production, the ability of this organism to produce cytotoxin(s) should not be overlooked. Some investigators have suggested that a cytolytic exotoxin similar to that produced by Clostridium difficile would probably account for the production of intestinal epithelial damage seen in gnotobiotic dogs infected with Campylobacter jejuni. ${ }^{16}$

Tissue culture techniques are being increasingly employed in the study of microbial toxins and provide a useful, sensitive and reproducible experimental system for the study of pathogenic mechanisms. In this present study, we were able to demonstrate that eight of eleven pathogenic strains of Campylobacter jejuni produced a substance which is cytotoxic to human cells in tissue culture. We believe that the results obtained in the present study probably represents the first report of an in vitro demonstration of cytotoxin in the cell-free filtrate of Campylobacter jejuni. The reproducible and constant occurrence of the morphological changes (cell rounding, loss of 
adherence and cell death) can be used as the basis of a biological assay for this substance. It is interesting to note that only the human cell lines were affected by the toxic factor. This may involve direct binding of the toxin to membrane receptors found in these cells but which are lacking in animal cells. However, the exact mechanism responsible for these cytopathic effects remains to be determined.

The sensitivity to trypsin and heat $\left(100^{\circ} \mathrm{C}\right)$ indicated that the toxic factor was protein in nature. By virtue of the fact that cytopathic effects were not observed with sonicated bacterial cell suggests that the toxin is an extracellular cytotoxin and is not cell associated.

It is well documented that an exotoxin of Shigella dysenteriae type 1 not only possesses cytotoxic activity to HeLa cells, but is found to also have enterotoxicity and neurotoxicity. ${ }^{17}$ Thus the possibility of this cytotoxin being an enterotoxin cannot be ruled out. Other biological activities will be looked into such as detection of thermolabile or thermostable enterotoxin by the classical assay (Y1 adrenal cell, Chinese hamster ovary cell and suckling mouse test).

Although only a small number of strains were tested in the present study it does appear that cytotoxin-producing capacity was detected in most of the strains tested (eight out of eleven). This is in agreement with a study of cytotoxin produced by Aeromonas hydrophila where 19 of 23 strains tested showed cytopathic effect on tissue culture cells. ${ }^{18}$ The exact reasons for cytotoxin non-production in the small number of negative cytopathic effect strains is not clear and it remains to be seen whether cytotoxin production is associated with pathogenesis and a more severe type of disease. It would also be of interest to determine whether strains of Campylobacter isolated from animals and from asymptomatic carriers are toxin producers. Detection of cytotoxic factor(s) from the stool samples of diarrhoeal cases due to Campylobacter jejuni should also be attempted.

The nature and role of this toxin await further purification and characterisation. Resolution of the crude culture filtrate by Sephadex gel chromatography is currently being studied so as to obtain a purer toxin preparation. Purification is important because the toxin may represent a minor component of the mixture of protein in the crude preparation as seen with the exotoxin of Shigella dysenteriae type 1 in contrast with the relative prominence of exotoxin in cultures of Vibrio cholerae, Corynebacterium diph- theriae and Clostridium tetani. The role of this toxin as a virulence factor needs to be investigated further to determine if the cytotoxin is directly involved in pathogenesis or whether it indirectly facilitates invasion and spread of the organism following entry via the alimentary tract.

\section{References}

' De Mol P, Bosmans E. Campylobacter enteritis in Central Africa (letter). Lancet 1978;i:604.

${ }^{2}$ Lauwers S, De Boeck M, Butzler JP. Campylobacter enteritis in Brussels (letter). Lancet 1978;i:604-5.

${ }^{3}$ Steele TW, McDermott S. Campylobacter enteritis in South Australia. Med J Aust 1978;2:404-6.

${ }^{4}$ Butzler JP, Dekegser P, Detrain M, Dehaen F. Related vibrio in stools. J Pediatr 1973;82:493-5.

${ }^{5}$ Pai CH, Sorger S, Lackman L, Sinai RE, Marks MI. Cam- $\vec{N}$ pylobacter gastroenteritis in children. $J$ Pediatr 1979;94:589- Wु

- Svedhem A, Kaijser B. Campylobacter fetus subspecies jejuni: A 을 common cause of diarrhoea in Sweden. J Infect Dis $\rightarrow$ 1980;142:353-9.

' Butzler JP, Skirrow MB. Campylobacter enteritis. Clin Gastroenterol 1979;8:737-65.

${ }^{8}$ Ruliz-Palacios GM, Escamilla E, Torres N. Experimental Campylobacter diarrhoea in chickens. Infect Immun 1981;34:250-5.

- Guerrant RL, Lahita RG, Winn WC, Roberts RB. Campyloba $\overrightarrow{0}$ teriosis in man: pathogenic mechanisms and review of bloodstream infections. Ann J Med 1978;65:584-92.

${ }^{10}$ Manninen KI, Prescott JF, Dohoo LR. Pathogenicity of Carif pylobacter jejuni isolates from animals and humans. Infect Immun 1982;38:46-52.

"McKendrick MW, Geddes AM, Gearty J. Campylobacter enteritis: A study of clinical features and rectal mucosal changes. Scand J Infect Dis 1982;14:35-8.

12 Skirrow MB. Campylobacter enteritis: a 'new' disease. $\mathrm{Br} \mathrm{Med} J$ 1977;2:9-11.

${ }^{13}$ Butzler JP. Infection with Campylobacters. In Williams JD, ed. Med Trop Infect London: Heinemann, 1978:214-39.

${ }^{14} \mathrm{King}$ EO. The laboratory recognition of vibrio isolated cases of human vibriosis. Ann N Y Acad Sci 1962;98:700-11.

is Finkelstein RA, LaRue MK, Johnston DW, Vasil ML, Cho GJ, $\frac{\cap}{0}$ Jones JR. Isolation and properties of heat labile enterotoxin(s) from enterotoxigenic Escherichia coli. $J$ Infect 3 1976;133:suppl:S210-S137.

${ }^{16}$ Prescott JF, Barker IK, Manninen KI, Miniats O. Campylobacter jejuni colitis in gnotobiotic dogs. Can J Comp Med 1981;45:377-83.

${ }^{17}$ Keusch GT. Pathogenesis of Shigella diarrhea. III. Effects of Shigella enterotoxin in cell culture. Trans $N$ Y Acad Sci 1973;35:51-8.

18 Donta ST, Haddow AD. Cytotoxic activity of Aeromonas hydrophila. Infect Immun 1978;21:989-93.

Requests for reprints to: Dr T Pang, Department of Medical Microbiology, Faculty of Medicine, University of Malaya, Kuala Lumpur, Malaysia. 